\title{
CLINICAL STUDY OF AIDED CORTICAL AUDITORY EVOKED POTENTIALS IN PEDIATRIC AUDITORY BRAINSTEM IMPLANTEES
}

\author{
Raghunandhan Sampathkumar, Mohan Kameswaran, Prashant Sharma, \\ Ranjith Rajeswaran, Chandrashekar Reddy
}

Department of Auditory Implants, Madras ENT Research Foundation, Raja Annamalai Puram, Chennai, Tamil Nadu, India

Corresponding author: Dr Raghunandhan Sampathkumar, Department of Auditory Implants, Madras ENT Research Foundation, Raja Annamalai Puram, Chennai, Tamil Nadu, India 600028 , e-mail: raghunandhansampath@gmail.com

\begin{abstract}
Background: Cortical auditory evoked potentials (CAEPs) reflect the function of the auditory thalamo-cortical pathways and the auditory cortex, and so are a window to the 'auditory brain'. They are a valuable prognosticator for predicting long-term outcomes in cochlear implantees. This preliminary study evaluated its use in pediatric auditory brainstem implant (ABI) who had bilateral Michel's deformity with cochlear nerve hypoplasia.
\end{abstract}

Objectives: To profile the aided CAEPs in children with ABI and to assess its efficacy as a tool for evaluating ABI outcomes.

Method: This prospective clinical study was performed in 3 pre-lingually deaf, non-syndromic children (aged 3-5 yrs) who had congenital bilateral hypoplastic cochlear nerves with Michel's cochlear deformity who underwent ABI at our institute. All implantees underwent CAEP testing at 6 months and 1 year post-implantation and their results were compared. To compare responses between the various electrodes in contact with the brainstem the $12 \mathrm{ABI}$ electrodes were divided into 4 groups (G1-G4). These groups were sequentially activated and the CAEPs recorded; the responses were compared to the overall CAEP response obtained by stimulating the entire electrode array. Testing comprised /m/, /g/, and /t/ acoustic stimuli and responses to them were recorded from each group of electrodes. Latency of P1, amplitude of P1 complex, and morphology of the responses were analyzed.

Conclusions: Results from our preliminary study showed that CAEP can be successfully recorded in ABI, and CAEP profiling can be an objective method of analyzing the optimal placement and function of the ABI electrodes on the brainstem. Thus CAEP is an efficient adjunct to electrically evoked auditory brainstem response (EABR) for testing ABIs. When stimulated via the ABI, CAEP may reflect re-organization of higher auditory centers and hence may be a good prognosticator for long-term assessment of $\mathrm{ABI}$ performance.

Key words: cochlear nucleus • auditory brainstem implant • electrically evoked auditory brainstem response (EABR) • cortical auditory evoked potential $(\mathrm{CAEP}) \cdot \mathrm{P} 1$ wave

\section{ESTUDIO CLÍNICO DE LOS POTENCIALES AUDITIVOS CORTICALES EVOCADOS ELÉCTRICAMENTE EN LOS NIÑOS-USUARIOS DE IMPLANTES AL TRONCO CEREBRAL}

\section{Resumen}

Introducción: Los potenciales auditivos corticales evocados (CAEP) son el reflejo del funcionamiento de la vía auditiva hipotálamo - corteza y del funcionamiento de la misma corteza auditiva, por lo que son una especie de ventana hacia "el cerebro oyente". Son un valioso predictor de los resultados auditivos de usuarios de implantes cocleares en el largo plazo. Este estudio preliminar ha tenido como objetivo evaluar su utilidad en el estudio de los niños que tuilizan los implantes cocleares al tronco cerebral (ABI), con aplasia bilateral de Michel y con hipoplasia del nervio coclear.

Objetivo: Elaboración de la descripción de los CAEP eléctricamente evocados en los niños con ABI y valoración de la utilidad de este estudio como herramienta de evaluación de los resultados ABI.

Método: El estudio prospectivo clínico ha sido realizado en tres niños con sordera prelocutiva, sin enfermedades adicionales (de 3 a 5 años), con hipoplasia bilateral del nervio coclear con aplasia de Michel, y a los que se les había insertado ABI en nuestro 
institudo. En todos los pacientes hemos realizado estudios de CAEP después de 6 meses y de 1 año después de la implantación y hemos hecho la comparación de sus resultados. Para poder comparar las respuestas entre distintos electrodos en contacto con el tronco cerebral, hemos dividido 12 electrodos ABI en 4 grupos (G1-G4). Dichos grupos fueron sucesivamente activados registrando CAEP: Las respuestas han sido comparadas con las respuestas generales CAEP obtenidas a través de la estimulación de toda la haz de electrodos. El estudio incluía estímulos acústicos $/ \mathrm{m} /, \mathrm{g} / \mathrm{y} / \mathrm{t} /$, hemos registrado la respuesta para cada uno de los grupos de electrodos. Hemos hecho análisis de latencia y de la amplitud de la onda P1 y de la morfología de la respuesta.

Conclusión: Los resultados de nuestro estudio prelminiar han demostrado que se puede llevar con éxito el registro de CAEP en pacientes con ABI, y que el CAEP puede ser un método objetivo del análisis de la localización óptima y del funcionamiento de los electrodos ABI. Por este motivo, CAEP es un estudio adicional eficaz, a parte de los potenciales auditivos del tronco cerebral evocados electrícamente (EABR) en el exámen de los pacientes con ABI. Durante la estimulación por el ABI, CAEP pueden reflejar la reorganización de centros auditivos superiores, por lo que pueden ser un buen indicador de los resultados de los pacientes con $\mathrm{ABI}$ en un plazo más largo.

Palabras clave: núcleo coclear • implante coclear al tronco cerebral • potenciales auditivos del tronco cerebral evocados eléctricamente $(\mathrm{EABR}) \bullet$ potenciales auditivos corticales evocados $(\mathrm{CAEP}) \bullet$ onda $\mathrm{P} 1$

\section{КЛИНИЧЕСКОЕ ИССЛЕДОВАНИЕ КОРКОВЫХ СЛУХОВЫХ ВЫЗВАННЫХ ПОТЕНЦИАЛОВ У ДЕТЕЙ, ПОЛЬЗУЮЩИХСЯ СТВОЛОМОЗГОВЫМИ ИМПЛАНТАТАМИ}

\section{Изложение}

Введение: Корковые слуховые вызванные потенциалы (САЕР) - это отражение функционирования корково-таламичного слухового пути и слуховой коры, поэтому они являются окном к «слышащему мозгу». Они - важный предиктор слуховых результатов пользователей улитковых имплантатов в течение длительного периода времени. Цель этого предварительного исследования - оценка их полезности в исследовании детей, пользующихся стволомозговыми слуховыми имплантатами (ABI), с двусторонней аплазией Мишель и гипоплазией улиткового нерва.

Цель: Описание электрически вызванных САЕР у детей с АВI и оценка полезности этого исследования в качестве инструмента для оценки результатов АВI.

Метод: Проспективное клиническое исследование проведено у 3 детей с прелингвальной глухотой, без других заболеваний (возраст 3-5 лет), которые имели двустороннюю гипоплазию улитковых нервов с аплазией Мишель. Детям были вживлены АВI в нашем институте. Мы провели исследования САЕР у всех пациентов после 6 месяцев и одного года после вживления и сравнили их результаты. Чтобы сравнить ответы между разными электродами, которые были в контакте со стволом мозга мы разделили 12 электродов АВI на четыре группы (G1-G4). Мы по очереди активировали группы, производя запись САЕР. Мы сравнивали ответы с общими ответами САЕР, полученными путем стимуляции целой связки электродов. Исследование охватывало акустические импульсы $/ \mathrm{m} /, \mathrm{g} / \mathrm{i} / \mathrm{t} /$, мы произвели записи ответов для каждой из групп электродов. Мы провели анализ латенции амплитуды волны Р1 и морфологии ответов.

Итоги: Результаты нашего исследования показали, что можно успешно произвести запись САЕР у пациентов с ABI, и что CAEР может быть объективным методом анализа оптимального размещения и действия электродов ABI, поэтому CAЕР - это эффективное дополнительное исследование кроме стволомозговых слуховых электрически вызванных потенциалов (EABR) в исследовании пациентов с ABI. Во время стимуляции ABI CAEP могут отражать реорганизацию высших слуховых центров, поэтому они могут быть хорошим предиктором результатов у пациентов с АВI в длительном периоде.

Ключевые слова: улитковое ядро • стволомозговый слуховой имплантат • стволомозговые слоховые электрически вызванные потенциалы (EABR) • корковые слуховые вызванные потенциалы (CAEP) • волна P1 


\title{
BADANIE KLINICZNE ELEKTRYCZNIE WYWOŁANYCH KOROWYCH POTENCJAŁÓW SŁUCHOWYCH U DZIECI KORZYSTAJĄCYCH Z IMPLANTÓW DO PNIA MÓZGU
}

\begin{abstract}
Streszczenie
Wprowadzenie: Wywołane korowe potencjały słuchowe (CAEP) są odzwierciedleniem funkcjonowania wzgórzowo-korowej drogi słuchowej oraz kory słuchowej, więc są oknem do 'słyszącego mózgu'. Są cennym predyktorem wyników słuchowych użytkowników implantów ślimakowych w długim przedziale czasu. To wstępne badanie miało na celu ocenę ich przydatności w badaniu dzieci korzystających z implantów słuchowych do pnia mózgu (ABI), z obustronną aplazją Michela i hipoplazją nerwu ślimakowego.
\end{abstract}

Cel: Stworzenie opisu elektrycznie wywołanych CAEP u dzieci z ABI i ocena przydatności tego badania jako narzędzia do oceny wyników ABI.

Metoda: Prospektywne badanie kliniczne zostało przeprowadzone u 3 dzieci z głuchotą prelingwalną, bez dodatkowych chorób (wiek 3-5 lat), które miały obustronną hipoplazję nerwów ślimakowych z aplazją Michela, i którym wszczepiono ABI w naszym instytucie. U wszystkich pacjentów wykonaliśmy badania CAEP po 6 miesięcach i po 1 roku od wszczepienia i porównaliśmy ich wyniki. Aby porównać odpowiedzi pomiędzy różnymi elektrodami będącymi w kontakcie z pniem mózgu, podzieliśmy 12 elektrod ABI na 4 grupy (G1-G4). Grupy kolejno aktywowaliśmy dokonując zapisu CAEP. Odpowiedzi porównaliśmy z ogólnymi odpowiedziami CAEP uzyskanymi przez stymulację całej wiązki elektrod. Badanie obejmowało bodźce akustyczne /m/, /g/ i /t/, dokonaliśmy zapisu odpowiedzi dla każdej z grup elektrod. Przeprowadziliśmy analizę latencji i amplitudy fali P1 i morfologii odpowiedzi.

Wniosek: Wyniki naszego wstępnego badania wykazały, że można z powodzeniem dokonać zapisu CAEP u pacjentów z ABI, i że CAEP może być obiektywną metodą analizy optymalnego umiejscowienia i działania elektrod ABI. Dlatego też CAEP jest skutecznym badaniem dodatkowym oprócz potencjałów słuchowych pnia mózgu wywołanych elektrycznie (EABR) w badaniu pacjentów z ABI. Podczas stymulacji przez ABI CAEP mogą odzwierciedlać reorganizację wyższych ośrodków słuchowych i stąd mogą być dobrym predyktorem wyników pacjentów z ABI w dłuższym okresie.

Słowa kluczowe: jądro ślimakowe • implant słuchowy do pnia mózgu • potencjały słuchowe pnia mózgu wywołanie elektrycznie $(\mathrm{EABR}) \bullet$ korowe potencjały słuchowe wywołane $(\mathrm{CAEP}) \bullet$ fala P1

\section{Background}

Normal maturation of central auditory pathways is a precondition for the optimal development of speech and language skills in children. There is considerable evidence from the recent literature that the auditory cortex is highly plastic for a sensitive period during development. If sensory input to the central auditory system is deprived during this period, it is susceptible to large-scale cross-modal reorganization exhibiting abnormal functional characteristics [1]. This emphasizes the phenomenon of a 'critical age' for implantation in congenital profoundly deaf individuals.

Factors like neural plasticity, neural scavenging, and cerebral re-organization have been extensively studied using advanced instruments in recent times [2,3]. With the advent of cortical auditory evoked potentials (CAEPs), the way is now open to objectively evaluate higher auditory centers functions and observe these factors. Cortical potentials have thus become an important diagnostic modality for evaluating higher auditory function in normal and hearing-impaired individuals. When CAEPs are recorded in normal, hearing-impaired, and cochlear implantees there are significant differences in the P1 wave characteristics $[3,4]$. This supports the idea that early intervention is paramount, so that by restoring vital inputs to the auditory brain there is the possibility that auditory stimulation and speech and language development can occur. CAEPs reflect the functioning of auditory thalamo-cortical pathways up to the auditory cortex. Their efficacy as a valuable prognosticator for predicting long-term outcomes in cochlear implantees have been well documented in the literature $[4,5]$. In cochlear implantees CAEPs seem to evolve over many years as they adapt to their implant-aided hearing; with time, performance generally improves.

A small number of children are born with bilateral cochlear nerve hypoplasia/aplasia, have Michel's cochlear deformity, or may develop a completely ossified cochlea subsequent to neonatal meningitis. In all these cases, cochlear implantation is impossible or pointless, and the only clinically available solution is auditory brainstem implantation (ABI). An intriguing question is whether the higher auditory centers might respond to ABI, since such centers have never been acoustically stimulated. It is possible that stimulating the cochlear nuclei at the brainstem and stimulating the cochlea might produce comparable responses. This study is a preliminary attempt to analyze the responses of the auditory brain using CAEPs in children implanted with an ABI. Our results provide a first insight into the behavior of higher auditory centers when stimulated via an ABI. This study suggests that CAEPs, which have shown to be a good objective tool for assessing the performance of cochlear implantees, may also be a good prognosticator for brainstem implantees. 
Table 1. Measures of $A B I$ outcome

\begin{tabular}{cccc}
\hline & \multicolumn{3}{c}{ Rehabilitation outcome } \\
\cline { 2 - 4 } & $\begin{array}{c}\text { Subject A } \\
\text { (6 months } \\
\text { and }\end{array}$ & $\begin{array}{c}\text { Subject B } \\
\text { (6 months } \\
\text { and }\end{array}$ & $\begin{array}{c}\text { Subject C } \\
\text { (6 months } \\
\text { and }\end{array}$ \\
\hline $\begin{array}{c}\mathbf{1 2} \text { months) } \\
\text { Category of }\end{array}$ & $\mathbf{1 2}$ months) & $\mathbf{1 2}$ months) \\
$\begin{array}{c}\text { auditory perception } \\
\text { (CAP) score }\end{array}$ & 2 & 3 & \\
\hline Speech intelligibility & 4 & 5 & 5 \\
rating & 2 & 2 & 4 \\
(SIR) score & 3 & 3 & 4 \\
\hline
\end{tabular}

\section{Methods}

This prospective clinical study was performed in 3 pre-lingually deaf candidates aged 3-5 years with congenital hypoplastic cochlear nerves and Michel's deformity of cochlea who underwent auditory brainstem implantation at our institute between July 2010 and June 2012. The main objective of our study was to profile the aided cortical auditory evoked potentials in children with $\mathrm{ABI}$ and to assess their efficacy as a tool for evaluating ABI outcomes. This research was approved by the institutional ethical research review board and informed written consent from the parents or legal guardians was obtained.

All three candidates were evaluated with CAEP prior to implantation with and without acoustic amplification and no significant responses could be obtained, indicating no auditory cortical activity. They were screened for speech, language, and neurological development and referrals were made to the implant audiologist, speech and language pathologist, and child psychologist for assessment of higher mental functions and intelligence quotient. They were also referred to the auditory-verbal rehabilitation therapist at our institute prior to surgery to help them adapt to the treatment. All three children received auditory brainstem implants (Med-El Pulsar, Innsbruck, Austria) from the same oto-neurological team as per standard protocols and they were uneventfully 'switched on' 8 weeks after the surgery. The implants were programmed using the default band settings in the mapping software and rehabilitated at our implant clinic for a period of one year. When stimulated via the ABI all three children showed satisfactory aided auditory thresholds within the speech spectrum. They developed significant auditory awareness and recognizable speech development as noted by their category of auditory performance (CAP) and speech intelligibility rating (SIR) scores at the completion of their rehabilitation period (Table 1).

CAEPs were tested at intervals of 6 months and one year in conjunction with their usual mapping schedules. In cochlear implantation, frequency-specific stimulation of the electrodes is due to tonotopic distribution of cochlear neurons, but the tonotopic pattern of the cochlear nucleus still remains to be explored. Most authors agree that in $\mathrm{ABI}$ it is not always possible to ascertain which electrode is stimulating which part of the cochlear nucleus. Due to wide and overlapping filter bands it is difficult to know exactly on which electrode what current was presented
Electrode Pad with Grouping

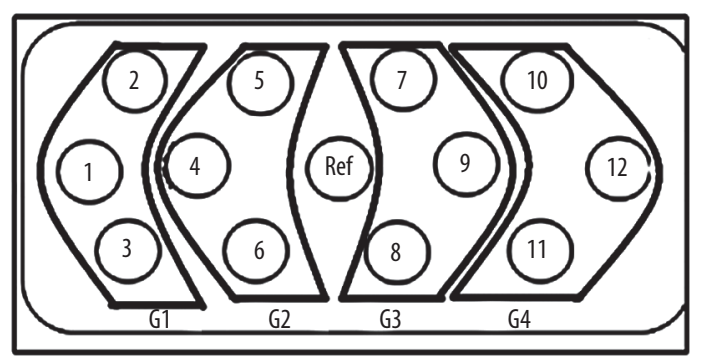

Figure 1. $A B \mid$ electrode pad and its groupings. The 12 electrodes of the Med-El Pulsar ABI were grouped into G1 (electrodes 1, 2, 3); G2 (electrodes 4, 5, 6); G3 (electrodes 7, 8, 9); and G4 (electrodes 10, 11, 12)

during live stimulation of an implant. Future research is needed to study the tonotopic responses of higher auditory centers to electrical stimulation.

To study this phenomenon we divided the 12 electrodes of the Med-El ABI electrode pad into 4 groups of 3 electrodes: G1 (electrodes 1, 2, and 3); G2 (electrodes 4, 5, and 6); G3 (electrodes 7, 8, and 9); and G4 (electrodes 10, 11, and 12) (Figure 1). When measuring CAEPs in an individual group, the other 3 groups of electrodes were switched off. Sequential paired tests of groups $\mathrm{G} 1+\mathrm{G} 2$ and $\mathrm{G} 3+\mathrm{G} 4$ and a combined electrode test of $\mathrm{G} 1+\mathrm{G} 2+\mathrm{G} 3+\mathrm{G} 4$ was also done and the results were compared (Figures 2-4).

CAEP waveforms were recorded with the standard CAEP instrument (NAL HearLab, Frye Electronics, USA). The aided cortical assessment module was used to record CAEPs with synthesized speech stimuli /m/ (low frequency), /g/ (medium frequency), and / $\mathrm{t} /$ (high frequency) via a loudspeaker at 55, 65, and $75 \mathrm{~dB}$ SPL when different electrode groups were activated. The stimuli were presented at an angle of zero degrees in front of the child at a distance of 5 feet. Speech processors were set to each child's usual program settings. Subjects were seated comfortably in a reclining chair placed in a sound booth and they watched a video tape or cartoon on a TV monitor placed in front of them. The video tape audio was on mute. Evoked potentials were collected using $\mathrm{Cz}$ as the active electrode ( $\mathrm{Cz}$ referred to the vertex midline placement). The reference electrodes were placed on the mastoid and a ground electrode on the forehead. The recording window included $-200 \mathrm{~ms}$ pre-stimulus time to $+600 \mathrm{~ms}$ post-stimulus time. Evoked responses were analog filtered from 1-30 Hz. Approximately 300 response sweeps were collected for each subject and averaging was automatically performed by the recording computer. Each test session lasted about 25 minutes, including electrode application and evoked response recording. Sweeps greater than $\pm 30 \mu \mathrm{V}$ were rejected off-line and the remaining sweeps were averaged to compute a final grand-averaged waveform for the individual subject.

In the NAL HearLab system, the default waveform reports are generated as average responses measured at one stimulus level. This average response is highlighted as a dark 

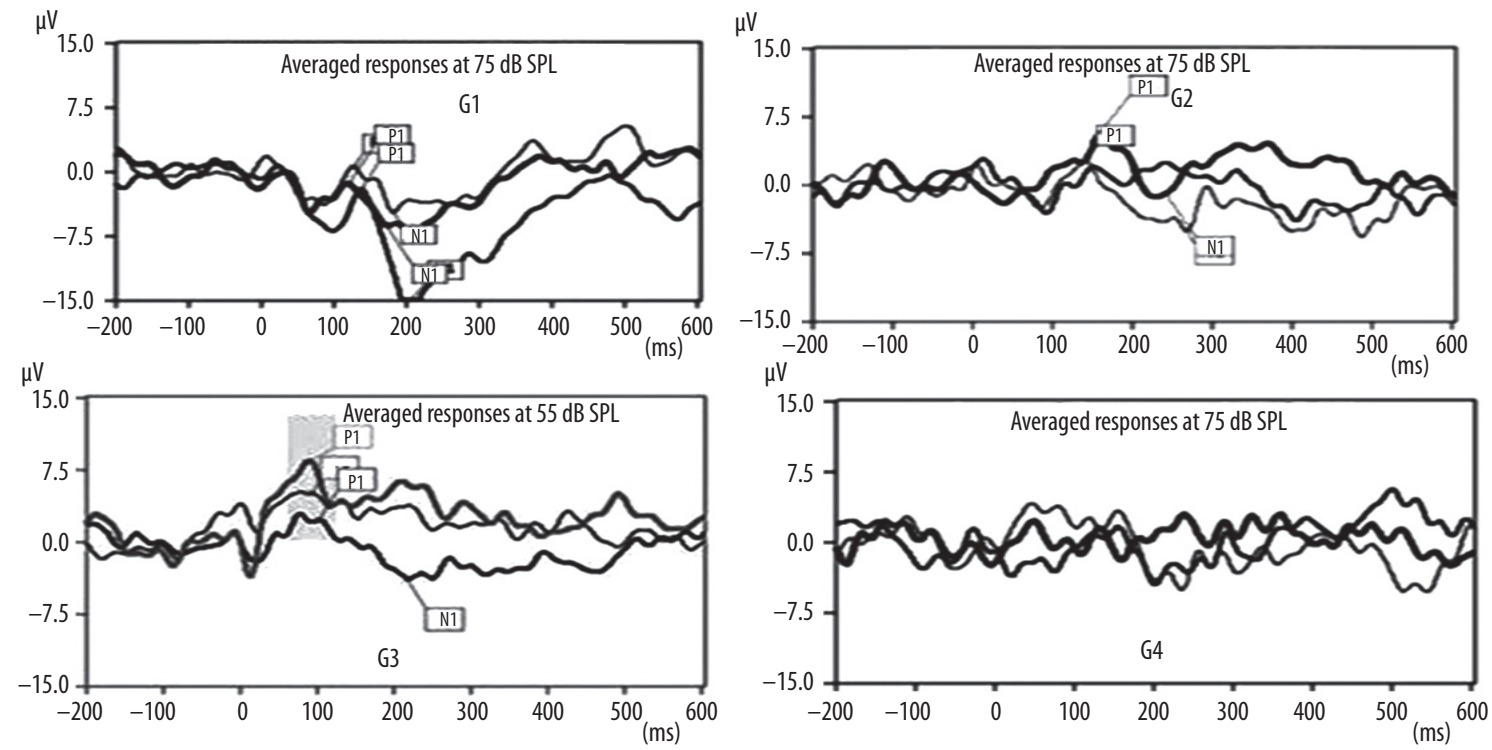

Figure 2. Averaged responses of CAEP P1 waveforms in response to three different frequency stimuli and arranged according to electrode grouping for patient A after 6 months of implant use. P1 waves were measurable for G1 and G2 electrode stimulation (top row) for all three stimuli at $75 \mathrm{~dB}$ SPL. P1 waves were also seen from stimulation of the $\mathrm{G} 3$ electrodes at $55 \mathrm{~dB}$ SPL (bottom left), but the wave was not recordable at any level of stimulation of the G4 electrodes (bottom right), possibly due to poor contact of these electrodes with the cochlear nucleus
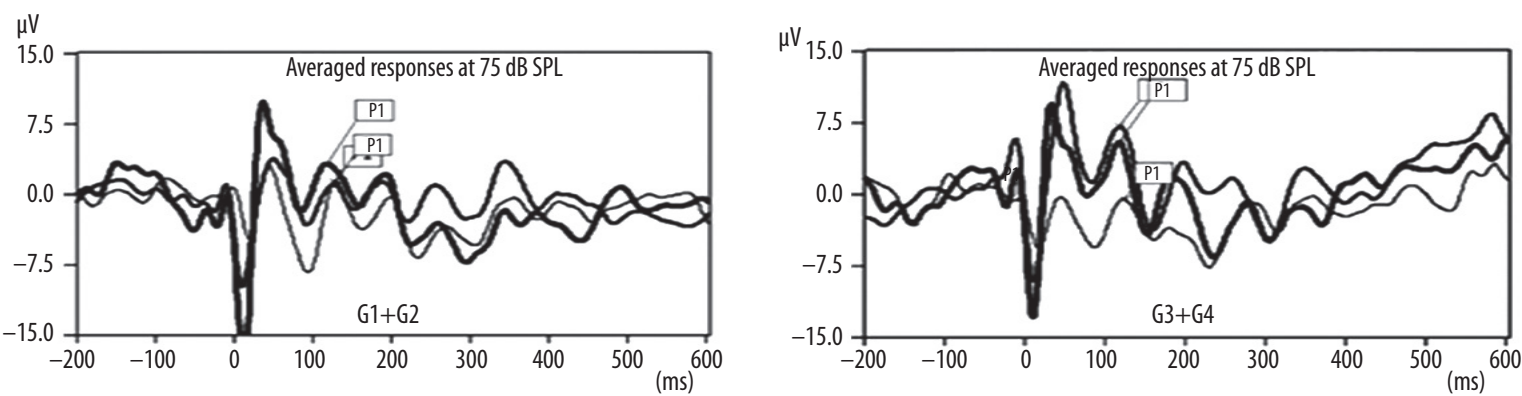

Figure 3. Averaged responses of CAEP P1 waveforms (dark bold lines) shown for Patient B after 6 months of implant use. CAEPs were measured for $\mathrm{G} 1+\mathrm{G} 2$ electrodes (left) and $\mathrm{G} 3+\mathrm{G} 4$ electrodes (right) for all three frequency stimuli at $75 \mathrm{~dB}$ SPL. The clear responses suggest there is proper contact and functioning of both these electrode groups

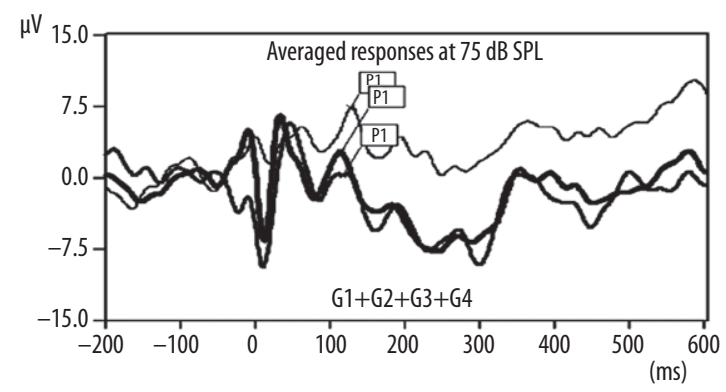

Figure 4. CAEP P1 waveforms are shown for patient $C$ after 12 months of implant use when recorded by combined stimulation of all four groups $(\mathrm{G} 1+\mathrm{G} 2+\mathrm{G} 3+\mathrm{G} 4)$ of the $\mathrm{ABI}$ electrode pad

wide line above other similar waveforms recorded for that stimulus level. We analyzed the parameters from this averaged waveform.
CAEPs in the three ABI children were recorded according to the various groups of electrodes described above, and were done by the same experienced implant audiologist. The waveforms were analyzed and the P1 wave was defined as the first robust positive cortical auditory evoked potential waveform in the $50-150 \mathrm{~ms}$ range [4]. P1 wave data, including amplitudes, latencies, and morphology were recorded for all three implantees at 6 months and 12 months after 'switch on' of the ABI device.

\section{Observations and Results}

Aided CAEP P1 waveform morphology noted among our ABI recipients were similar to those aided through a cochlear implant. The latency of the P1 wave in all 3 of our subjects was between 100-150 ms, which is comparable to the P1 latency evoked by a cochlear implant. Even though we expected the ABI-evoked CAEP to have a shorter latency than those evoked by a CI, we found no marked difference. In subject A, peaks could not be recorded in G4 
Table 2. Latency of CAEP from P1 waveforms for combined stimulation of all groups in ABI electrode pad at $75 \mathrm{~dB}$ SPL

\begin{tabular}{cccc} 
& \multicolumn{2}{c}{ Latency (milliseconds) } \\
\cline { 2 - 4 } Stimulus & $\begin{array}{c}\text { Subject A } \\
\text { (6 months and } \\
\mathbf{1 2} \text { months) }\end{array}$ & $\begin{array}{c}\text { Subject B } \\
\text { (6 months and } \\
\mathbf{1 2} \text { months) }\end{array}$ & $\begin{array}{c}\text { Subject C } \\
\text { (6 months and } \\
\mathbf{1 2} \text { months) }\end{array}$ \\
\hline /m/ & 134 & 122 & 149 \\
(low frequency) & 139 & 127 & 123 \\
\hline /g/ & 124 & 120 & 131 \\
\hline (medium frequency) & 113 & 114 & 111 \\
\hline (high frequency) & 117 & 108 & 121 \\
\hline
\end{tabular}

Table 3. ABI-aided auditory thresholds after 12 months of implant use

\begin{tabular}{cccccc}
\hline & \multicolumn{5}{c}{ Aided threshold (dB SPL) } \\
\cline { 2 - 6 } & $\mathbf{5 0 0 ~ \mathbf { ~ z ~ }}$ & $\mathbf{1} \mathbf{~ k H z}$ & $\mathbf{2} \mathbf{~ k H z}$ & $\mathbf{4} \mathbf{~ k H z}$ & $\mathbf{8} \mathbf{~ k H z}$ \\
\hline Subject A & 40 & 30 & 40 & 50 & 45 \\
\hline Subject B & 15 & 20 & 30 & 25 & 30 \\
\hline Subject C & 30 & 35 & 35 & 40 & 35 \\
\hline
\end{tabular}

(electrodes 10,11,12), possibly due to lack of closeness of these electrode to the brainstem. However, non-auditory sensations were present when electrodes 10,11 , and 12 were switched on and stimulated in this patient. The G4 group of electrodes were probably not in proper contact with the cochlear nucleus and were stimulating a different group of neurons in the brainstem, and so giving no P1 responses on CAEP testing. This phenomenon was not observed in the other two patients, in whom all groups gave recordable CAEP waveforms. Thus CAEP testing can indicate whether an ABI implant is in proper contact with the cochlear nucleus.

Non-auditory sensations are commonly present in adults stimulated with ABI, but this is not the case in children, a result which can be attributed to their lack of behavioral feedback. CAEPs may hence shed some light on how to correctly identify ABI electrodes that evoke non-auditory sensations, especially in children. The morphological wave patterns were found to be more robust when all four groups were stimulated together (Figure 4), and their amplitude and latencies were found to be similar to waveforms recorded by the individual electrode groups.

Acoustic stimuli given at three different levels and at three different frequencies evoked similar CAEP wave responses. We could not elicit a consistent linear progression in wave amplitude or latency with increasing stimulus levels. Thus we were not able to study phenomena like amplitude growth functions, optimal gain, or pitch ranking of the ABI electrodes. CAEP characteristics evoked by stimulation of all electrodes were found to be comparable to responses from individual electrode groups. However, such comparisons did not give information on an optimal stimulus level of the ABI implant (Figures 2-4); we could not infer which group of electrodes was producing more robust CAEP waveforms and better cortical auditory stimulation. For all three acoustic stimuli there was no statistically significant difference between the amplitude or latency measurements recorded while stimulating the complete electrode pair versus individual electrode groups. A summary of the latency measures for the three subjects measured at 6 months and 12 months of implant use is shown in Table 2. The ABI aided auditory thresholds of these 3 patients as recorded after 12 months of implant use is shown in Table 3.

\section{Discussion}

ABIs bypass the hypoplastic or absent cochlear nerves and stimulate the cochlear nucleus directly, thereby restoring auditory sensation. The implant is placed by accessing the cerebello-pontine angle in the lateral recess of the fourth ventricle abutting the cochlear nucleus. For comprehensive auditory stimulation the electrode needs to be in contact with the dorsal cochlear nucleus and the posterior end of the ventral cochlear nucleus. The conventional tool for objective assessment of optimal placement and function of $\mathrm{ABI}$ has been the electrically evoked auditory brainstem response (EABR). Intra-operative EABR objectively identifies the correct location of the electrodes with respect to the cochlear nucleus and also confirms optimal implant function. After switch-on, EABR thresholds can be used as a guide to program the mapping levels in the $\mathrm{ABI}$. EABRs are sensitive predictors of ABI function, although sometimes, for various reasons, the EABR responses are unsatisfactory in spite of correct placement of the ABI. EABR is a time-consuming and tedious method for assessing individual ABI electrodes. Factors during testing like muscle artifacts, innate EEG interference, and electrical interface mismatch may affect EABR waveforms, resulting in inconclusive recordings. Hence a dilemma sometimes arises when, despite good intra-operative EABR, post-operative electrode functions may not 
give optimal recordings. There is also a small chance of ABI electrode migration within the lateral recess, possibly influenced by CSF flow and pulsations within the recess. In such cases EABR waveforms can change significantly in their amplitude and waveform shape or may even be unrecordable. EABR reflects the brainstem responses evoked by an electrode and simultaneous profiling of all electrodes with EABR is not practical.

Among brainstem implantees, phonemic awareness, auditory discrimination, and speech understanding have not been clearly achieved to date. PET scans, CT scans, and fMRI may play an important role in identifying cortical activity in children with ABI, but they do not provide electrode-specific or stimulus-specific information. The P1 wave of the CAEP has been established as a biomarker for assessing the maturation of the central auditory system. ${ }^{2}$ This test determines if acoustic stimulation at conversational levels are effectively transduced by the child's hearing apparatus and detected at the level of the auditory cortex. Cortical potentials have previously enabled us to objectively study the phenomenon of neural reorganization in higher auditory centers in children who have received CIs at an early age. This same phenomenon should apply to electrical stimulation among pediatric ABI patients and may therefore be able to be explored using CAEPs. This thought initiated our interest in studying the CAEP waveforms in a group of pediatric $\mathrm{ABI}$ recipients.

The latency of the P1 wave is thought to reflect the sum of synaptic transmission delays throughout the central auditory pathways. Latency of P1 changes as a function of age and reflects the maturation of central auditory pathways occurring in response to auditory stimulation. Lack of activity in the infra-granular layers of the cortex in response to sound and decoupling of communication between the primary and secondary auditory areas have been implicated for such changes in P1 waveforms, which have been noted among congenital profoundly deaf individuals [5]. Earlyonset auditory deprivation relates to waveform negativities, polyphasic morphology, and low amplitude waveforms which have often been observed in children who have not received adequate input to their central auditory pathway within the optimal timeframe. This finding is seen in the pre- and post-operative ABI CAEP waveforms of our study group, which are poor in comparison to a normative CAEP.

Sharma et al. [2] examined P1 latencies in children with cochlear implants and found prolonged latencies compared to normal hearing children, especially when they were implanted late. Further, P1 wave latency appears to progress for some few years after implantation. With $\mathrm{ABI}$, there is currently no literature confirming CAEP trends. Our preliminary study has shown that the morphology of the P1 wave is similar to those obtained in a cochlear implantee. The CAEP waveforms we noted from ABI were comparable to those aided through cochlear implants. In our preliminary work, we have not seen consistent progression in latency among all our 3 subjects, but we feel that the $\mathrm{P} 1$ latency recorded in our ABI recipients tend to be similar to those obtained among cochlear implantees (even though theoretically we expect the latency of $\mathrm{P} 1$ in $\mathrm{ABI}$ to be shorter than in $\mathrm{CI}$ ). This interesting phenomenon needs to be explored in further detail in a larger cohort.
The latency measures noted in aided CAEPs evoked by CIs and $\mathrm{ABI}$ s suggest that both $\mathrm{CI}$ and $\mathrm{ABI}$ electrically stimulate the cochlear nucleus and higher auditory centers in a similar way. CAEP stimulation given at different acoustic levels and at different frequencies evoked the same kind of aided responses through ABI. Thus we are not able to categorize amplitude growth functions, optimal gains, or pitch ranking of the electrodes in the brainstem as done with an EABR. This means that the cochlear nucleus may not be as tonotopically organized as the cochlea, and stimulation of different groups of electrodes may not reflect frequency-specific stimulation of higher auditory centers.

Comparing the overall stimulation of electrodes with the cumulative responses of individual electrode groups may not be valid and might not reflect on the optimal performance of an ABI implant. Stimulating electrode groups individually evoked adequate CAEPs, but such an arrangement may still not give optimal ABI function. Interestingly, we have not seen any noticeable differences in the CAEP parameters between our subject A (3 years) and subject C (5 years). Duration of deafness is an interesting parameter about which further research is necessary. Perhaps CAEP can help in evaluating central neural re-organization, but we believe that such neural scavenging can be better studied with radio-imaging tools like PET-CT and NIRS.

Our preliminary study implies that CAEPs can help objectively confirm that stimulation of higher auditory centers can be done through an ABI, and it can also confirm whether an implant is in proper contact with the cochlear nucleus. In this way, CAEPs might be useful as an adjunct tool to EABR in assessing the prognosis for auditory brainstem implantees. Absence of CAEPs via ABI may indicate improper contact of an electrode with the cochlear nucleus, and CAEPs may also be useful as a vital trouble-shooting tool to identify device failure.

Another unknown factor in patients with congenital absence of the cochlea and the cochlear nucleus is the degree of development of the brainstem cochlear nucleus. It is generally assumed that even in patients with absent cochlear nerves the cochlear nuclei are developed and centrally connected. In fact, this presumption forms the very basis of auditory brainstem implantation in children. However, this may not always be the case. Surgeons and audiologists should always consider this crucial fact and include it in the pre-implantation counseling process. In a few such patients one can expect absent or poorly defined EABRs and CAEPs despite proper placement of the electrode in the lateral recess.

Our novel experience is a preliminary step towards the assessment of ABI through aided CAEPs; however, a larger sample needs to be studied for a longer period of time in order to draw solid conclusions. This might be possible in a multi-center study involving various ABI implant centers that perform CAEPs.

\section{Conclusions}

CAEP is biomarker to monitor the maturation of the auditory cortex. The morphology and latency of the response helps in gauging the maturation of the auditory cortex in 
children with ABI and it can be correlated with the outcome over time. Our CAEP study leads us to conclude that central auditory reorganization does take place with an $\mathrm{ABI}$, however it does take time to establish. It is possible to profile ABI electrodes by grouping them in a predefined way and stimulating the auditory cortex. Optimizing the stimulation parameters is a very challenging task in programming an ABI. Amplitude of the CAEP may help as a guide in programming ABIs in young children.

Along with EABR, CAEP has proven to be an additional objective tool for assessing the optimal functioning of an ABI. Our study is preliminary and suffers from a small sample size, but nevertheless it provides a valuable insight into ABI outcomes and provides a simple way to assess the integrity of the device. Future directions for research into this field should include studies to evaluate tonotopicity, amplitude growth functions, and the pitch-ranking properties of the cochlear nucleus and the higher auditory centers; radiological studies are also needed of the three-dimensional size of the cochlear nucleus and its correlation with CAEPs.

At present there are only a few centers across the world who are studying ECAEP (electrically evoked CAEP) in ABI subjects. Publications have not yet emerged and we are looking forward to insights from these centers. We have attempted to use acoustic stimuli to evoke CAEPs in our study group, but we believe a future focus should be on studying the correlations between (electrical) ECAEP versus (acoustic) ACAEP in a group of ABI users. Such a study would show variations in P1 latencies when evoked by two different types of stimuli. CAEPs have opened a new window to clinical study of the intriguing changes that happen in a brain due to auditory stimulation.

\section{References:}

1. Sharma A, Dorman MF, Spahr AJ. A sensitive Period for the Development of the Central Auditory System in Children with Cochlear Implants: Implications for Age of Implantation. Ear Hear, 2002; 23: 532-39.

2. Sharma A, Nash AA, Dorman MF. Cortical development, plasticity and re-organization in children with cochlear implants. J Commun Disord, 2009; 42: 272-79.

3. Kirk K, Miyamoto R, Lento C, Ying E, O’Neill T, Fears B. Effects of age at implantation in young children. Ann Otol Rhinol Laryngol Suppl, 2002; 189: 69-73.
4. Dorman, MF, Sharma A, Gilley P, Martin K, Ronald P. Central auditory development: evidence from CAEP measurements in children fit with cochlear implants. J Commun Disord, 2007; 40: 284-94.

5. Kral A, Tillein J, Heid S, Hartmann R, Klinke R. Postnatal cortical development in congenital auditory deprivation. Cereb Cortex, 2005; 15(5): 552-62. 